\title{
1. The many faces of the ever-changing multinational enterprise
}

Yair Aharoni

\section{INTRODUCTION}

The phenomenon of multinational enterprises (MNEs) was an enigma for classical economists. There was no satisfactory explanation for their existence. Why do some firms erect plants in foreign countries and others not? Why and when do firms prefer foreign investments to exports? Indeed, international economic textbooks chose for many years to ignore the phenomena of foreign direct investment (FDI) and MNEs and concentrated instead on international trade. While most international economists ignored FDI, there were a few exceptions. John Dunning studied American investment in the British manufacturing industry (1958). In the 1960s, Raymond Vernon directed the Multinational Enterprise Project at Harvard Business School that assembled data on U.S.-based multinationals. Because his major concern was the relations of nation state governments and MNEs, Vernon defined a firm as being multinational if it was listed in Fortune 500 and had subsidiaries in at least six countries (Vernon, 1971). His doctoral candidates looked at these organizations in terms of finance, organization, production, marketing, and business-government relations.

Stephen Hymer's doctoral thesis of 1960 (published in 1976) was perhaps the first attempt of an economist to offer a theory of why a firm produces abroad rather than simply exports from its home country. His explanation assumed that such firms have some monopolistic advantage that allows them to overcome the additional costs of foreign operations what Zaheer (1995) later termed "liability of foreignness" - and compete successfully against domestic firms. It stands to reason that prior investments in research and development $(R \& D)$ and marketing resulted in these disproportional advantages. Since Hymer's seminal work, firm-specific advantages (FSAs) or ownership advantages have become a cornerstone of international business (IB) theory.

Moreover, the theory of IB assumed that MNEs "concentrated mainly in knowledge-intensive industries characterized by high levels of research and development (R\&D) expenditure and advertising expenditure, and by 
the employment of skilled labor" (Buckley and Casson, 2009: 1563). Firms in emerging economies were assumed to lack the capabilities to compete against these MNEs and should concentrate on being production workshops - based on the lower cost of labor in them.

In 1977, John Dunning published the first statement of the ownershiplocation-internalization (OLI) paradigm (Dunning, 1977) - perhaps the closest thing to an IB theory model. He identified ownership, location, and internalization as three potential sources of advantage that may explain a firm's decision to become a multinational. Ownership advantages, following Hymer, explained why some firms but not others were MNEs: these firms possessed some FSAs that allowed them to overcome the costs of operating in a foreign country. Location advantages, later called countryspecific advantages (CSAs) by Rugman, focused on the question of where an MNE chooses to locate. Finally, following Coase's 1937 seminal work, Buckley and Casson (1976) introduced to the literature the term "internalization advantages," referring to those advantages that explain why certain activities are carried out within firms while others are done through arm's-length transactions. Since the 1977 paper, Dunning later refined and extended his paradigm (Narula, 2006, 2010). In each case he attempted to include new developments. Yet the OLI paradigm is not a theoretical model.

Other researchers have analyzed MNEs through different lenses. Forsgren (2013), for example, analyzed and compared six theoretical perspectives of the MNE used by different researchers to explain the MNE as an actor in the global economy:

1. The first perspective is that of Hymer where the MNE is portrayed as dominating because of its market power.

2. The second perspective is the coordinating MNE, based on transaction cost theory. It emphasizes the ability of the firm to internalize such transactions and coordinate them across borders.

3. The knowing MNE is the third perspective: a tale of value creation. This perspective is rooted in the resource-based view of a firm. It emphasizes the process of creation of unique knowledge.

4. A fourth view, according to Forsgren, is the designing MNE. This approach stresses the ability of MNEs to adapt their organization and control system to changes in the environment.

5. A fifth perspective is the networking multinational: a tale of business relationships. It is based on resource dependence theory and emphasizes business relationships with customers, suppliers, and other counterparts. The business network, in which each subsidiary is embedded, has a profound impact on the strategic decisions of the multinational firm. 
6. The sixth and final perspective emphasizes legitimacy and power and the political side and role of the MNE.

All these explanations seem to have ignored several issues. First, while Vernon defined an MNE as operating in at least six countries, The United Nations Conference on Trade and Development (UNCTAD) and most scholars today accept the definition of an MNE as operating in two countries or more. This new definition more than doubles the reported number of MNEs and changes their capabilities. This difference in definition is particularly important when the MNE-government relations are considered. The more spread out the MNE, the greater its ability to avoid single state regulations. The changed definition also includes a large number of small and medium-sized enterprises (SMEs). Second, MNEs were often portrayed as giant firms, but size does not determine their nature as MNEs. Third, until very recently most academic work on MNEs analyzed the "greenfield" mode of FDI. Yet, according to UNCTAD, cross-border mergers and acquisitions (M\&As) accounted for over 80 percent of worldwide FDI in the 1990s; the principal motive for an M\&A may be synergy or gains from absorbing a rival. For emerging-market MNEs (EMMNEs), for instance, M\&As allowed faster access to resources, brands, markets, and advanced technologies - combined with lower costs. As discussed below, more recent collaborations and partnerships are designed to exchange - rather than transfer - technology and to develop new products. Further, many FDIs are not accounted for in the official statistics. Thus, code-sharing agreements and other forms of strategic alliances are excluded.

Finally, until the 1980s it was taken for granted that MNEs were firms from developed markets. The home country of the MNEs was either the United States or a Western European country. Since the 1970s, Japanese firms, and later South Korean firms, have joined this exclusive club. Today, there are more than 104,000 firms qualified as MNEs and the home country of almost a third of them is in an emerging economy. These firms are bullish and increase their foreign operations rapidly. In 2012, outflows of FDI from developing countries were $\$ 480$ billion - 31 percent of global outflows (UNCTAD, 2013). Indeed, in the last few decades, a spate of firms from emerging-market economies increasingly expanded their operations by FDI in other countries, including the advanced developed economies. Thus, any FDI theory that does not explain and account for their operations is woefully inadequate.

This chapter starts with a short description of the proliferation of the EMMNE and the various explanations for the reasons behind their rise. It is shown that there are many types of EMMNEs. Their operations can 
include everything from sweatshops to R\&D. Some were able to develop a global brand while others were not. A few grew into giants while many remained SMEs. Many of them have only one FDI. Others have spread their subsidiaries into many countries. Some enjoy support of their home governments; others base their operations on other advantages. While some EMMNE FDIs are resource seeking, an increasing number of EMMNEs operate in knowledge-based industries. The latter type has tended to pursue interrelated asset-augmenting and market-seeking strategies in North America and Europe. To be sure, the majority of them are service firms, a fact often ignored by researchers.

In short, there are many faces of MNEs. Therefore, it is futile to look for a universal IB theory. Instead, it is useful to understand the impact of different contingent variables, for example, in searching for the explanatory factors on whether and how fast knowledge-based EMMNEs can close the gap between them and their competitors from advanced economies. International business researchers should move from rigid universal rules to a contingency theory. To some extent, MNEs are also a moving target: they develop, learn and adapt to a changing environment. If they do not, they are doomed and may cease to exist. Further, there are many ways to gain competitive advantages. The tendency to assume all firms classified as belonging to the same industry compete against each other is quite wrong. Rather, firms search for ways to be perceived as unique and be differentiated from other firms. In other words they try to be monopolies in a welldefined segment rather than competitors in a vast industry.

Moreover, theory should recognize and adapt to environmental changes. Specifically, technological changes reduced significantly the magnitude of the liability of foreignness. As one example, cyberspace is open to all. Advances in information technology (IT) and the use of the Internet made the world more accessible and knowledge about international rules as well as other countries, competitors, suppliers, customers, and products readily available. Search engines such as Google allow firms to reduce the costs of search significantly. Even if the world is not flat, it is certainly much easier and significantly less costly to start and manage a multinational enterprise today. Indeed, a large number of SMEs from all sorts of countries are able to operate regionally if not globally. In other words, considerably fewer FSAs are needed to operate outside the home country.

At the same time, as a result of globalization firms must compete on a scale that is larger than that of the home country. The dismantling of many government-imposed barriers to entry force firms to achieve worldclass competitiveness since they cannot hide behind import restrictions any longer. Instead, they face competition from the advanced countries' MNEs attracted to the rapid growth emerging economies. In fact, in 2012 for the 
first time, 52 percent of FDI inflows were made in developing economies (UNCTAD, 2013). Firms based in emerging economies find that they can no longer rely only on lower cost. They must gain scale by FDI. They also must gain skills by acquiring foreign firms. If countries would continue to adhere to liberal economic policies, more firms in various industries would have to look abroad. In certain strategic industries, such as the defenserelated ones (and perhaps also when the investing firm is state owned or controlled), FDI would be restricted by governmental decrees. All in all, EMMNEs are not a fleeting phenomenon, destined to disappear. No universal answer can be provided to explain their operations.

\section{THE EMERGENCE AND GROWTH OF EMMNES}

The first wave of recognition by researchers of the existence of EMMNEs appeared in the 1980s. Lou Wells published his book, Third World Multinationals (1983), and a few other scholars researched or discussed these same firms (Lecraw 1977; Ghymn, 1980; Kumar and McLeod, 1981; Lall, 1983). These researchers attempted to explain how it was possible for EMMNEs to compete against rivals from developed economies. Two sets of explanations were suggested. First, these firms used outdated and simple technologies, produced low-priced products, and focused on laborintensive production because of the abundance of inexpensive labor in their home countries. Second, EMMNEs enjoyed a greater capability for adapting products to the specific demands of import-protected environments (Lall, 1983; Wells, 1983). In other words, these firms enjoyed advantages because they learned to operate in underdeveloped environments. Since the advantages were related to operations in developing markets, it was taken for granted that EMMNEs could not compete against firms from developed countries or in free-market economies.

Since the 1990s, however, a growing number of EMMNEs have competed quite successfully in advanced and free-market economies. They are challenging some of the world's most accomplished advanced-economy MNEs (AEMNEs) in a wide variety of industries, thus changing the competitive landscape. Some of these firms are resource seekers, but an increasing number operate in knowledge-based industries, leapfrogging to catch up fast in competitiveness with developed markets' MNEs. These exemplary firms are learning to build more capabilities than just relying on cost advantages. Their success is based on innovation, operational excellence, quality, branding, and customer service. Indeed, until the end of the 1990s, innovation was perceived to be only in the triad. Today, much $\mathrm{R} \& \mathrm{D}$ is carried out in contract research labs in India or China and these 
countries are also able to create knowledge-based MNEs. The number of patents registered in the U.S. by these countries has mushroomed (BCG, 2013: exhibit 6).

The proliferation and unexpected rise to prominence of these EMMNEs led to a spate of research papers focusing on different countries (Jones, 2005; Goldstein 2007, 2008a, 2008b, 2009; Goldstein and Pananond, 2008; Jones and Khanna, 2006; Narula 2012; Ru-Shiun et al. 2012) and raised several interesting issues. First, how can these firms compete? In other words, do they enjoy ownership advantages, and if so what are they? Second, can the existence of EMMNEs be explained by extant theories, or does their rise imply the demise of these theories? Several answers were provided to the first question. Many researchers claim these new MNEs do enjoy FSAs that are somewhat different from those possessed by established developed countries' MNEs. Thus, Zeng and Williamson (2007) and Williamson and Zeng (2009) claim that some emerging-market firms have developed process innovations that allow them to produce Westerntype goods at lower cost and successfully market them abroad. These EMMNEs leverage home-country-specific advantages such as natural resources and cheap labor. Other researchers suggest that EMMNEs developed strategic innovations that enabled them to exploit their latecomer and peripheral status. These firms are said to enjoy many different types of advantages, which are different from the traditional advantages analyzed in MNEs from advanced countries. For example, they are said to have better political capabilities, or superior abilities to operate in harsh institutional environments in other developing countries. These EMMNEs are said to be more used to dealing with unstable governments in their home country. Therefore, they are able to succeed in foreign countries characterized by a weak institutional environment (Cantwell and Barnard, 2008; Cuervo-Cazurra and Genc, 2008; Dunning and Lundan, 2008). Buckley et al. (2007) stress privileged access to cheap capital, either because of government subsidies or as a result of imperfections in the domestic capital market. Also suggested is the leverage of home-countryspecific advantages such as natural resources and cheap labor (Cantwell and Barnard, 2008; Rugman, 2009; Williamson and Zeng, 2009); and access to cheap capital because of imperfections in the domestic capital market (Buckley et al., 2007). Others argue that EMMNEs do not go abroad to exploit existing FSAs, but rather to explore new ones. In other words, they internationalize in order to build their advantages and desire to engage in knowledge asset seeking in foreign markets (Hoskisson et al., 2000; Mathews, 2002a, b; Dunning, 2006; Goldstein, 2007; Luo and Tang, 2007; Dunning et al., 2008). Yet, it still remains unclear under what conditions EMMNEs are likely to compete successfully with AEMNEs on 
a global scale (Ramamurti, 2009). A useful discussion on the debate may be found in Cuervo-Cazurra (2012) and Ramamurti (2012) and so is not repeated here.

As to the second question - can the existence of EMMNEs be explained by extant theories, or does their rise imply the demise of these theories? Mathews claims that so-called "'Dragon Multinationals,' help to expose the weaknesses and limits of traditional accounts of MNEs and of the existing theories and frameworks of International Business" (Mathews, 2006a: 8) because, contrary to the predictions of the OLI that MNEs venture abroad to exploit their FSAs, the Dragons have expanded abroad without such FSAs: "To tackle the case of these latecomers from the periphery [...] we need a framework that emphasizes how resource-poor companies can utilize the linkage and leverage to expand their operations" (Mathews, 2006b: 154). Mathews indeed proposes such a framework, the LLL framework, in which the Dragons' international expansion is seen as a search for external resources that can be explained in terms of resource linkage, leverage, and learning (for comments see Dunning, 2006).

Hennart proposed what he called a "bundling model." The model argues that the profitable sale of any product or service in any given host market requires the bundling of intangibles such as technology and brand names with complementary local resources. These resources include the knowledge of how to incorporate these intangibles into products that meet the needs and tastes of local consumers, the logistics necessary to put products within their reach, and all of the other inputs necessary for local production. Hennart argued that, contrary to what the OLI assumes, these complementary local resources are rarely sold on competitive markets especially in emerging markets, they are often monopolized by local firms. (Hennart, 2012: 183). He suggested that the OLI paradigm suffers from the basic flaw of assuming that location advantages (or CSAs) are freely available to all firms. His bundling model is based on the premise that local firms can enjoy specific location advantages not available to other firms.

On the other hand, Rugman and $\operatorname{Li}(2007)$ have forcefully argued that the theory need not be amended. Present Chinese foreign investments are ill advised and not sustainable. Rugman and Li write (2007: 333):

Basic theory suggests that multinational enterprises succeed when they develop knowledge-based capabilities, often called firm-specific advantages (FSAs). In China's case, its large MNEs have few such knowledge based FSAs. Instead, they are building scale economies based on China's country-specific advantages (CSAs) in relatively cheap labor and natural resources [. . .] However, there need to be more than economies of scale in the case of China's MNEs, as such scale advantages reflect a country factor available to all firms, rather than being an FSA. 
In a later work, Rugman asks (2009: 53): "When will China generate its own world-class MNEs? The answer is - not for 10 or 20 years." Similarly, Lessard and Lucea (2009: 288) argue that "EMNEs that base their international competitive advantage on the basis of privileged access to natural resources or cheap unskilled labor are, almost by definition, non-sustainable: natural resources are finite and wage differentials with more advanced markets may narrow quickly as emerging markets develop." In other words, theory is right and the success of firms from emerging economies is impossible. In between are those that claim that the core explanation for the existence of MNEs is valid. The new MNEs do possess valuable but not conventional FSAs, such as political and networking skills. For example, "firm specific advantages originate from, or are reinforced by, home country institutions" (Wang et al., 2012: 671).

All of the abovementioned researchers discuss EMMNEs as if they are all the same. Yet EMMNEs are far from being identical and universal rules are impossible. A theory of MNEs should become a contingency theory, explaining the behaviors of firms from different industries, cultures, social norms and regulations, motivations, sizes, years of operations, home base, and ownership - SOEs are not the same as family-owned and these are different to investor-owned. Universal explanations are doomed to be true only under certain circumstances. As one example, EMMNEs are said to lack the FSA of a strong brand. This may be true: several EMMNEs' management chose to acquire established brands in the developed markets. One example is the acquisition of Tetley Tea and Daewoo Trucks by the Indian Tata Motor Company. Another example is TCL, a Chinese consumer electronics company that acquired the French Thomson TV brand to break into the European market. Lenovo acquired the PC brand, the Thinkpad, from IBM. Yet other EMMNEs - mainly from large countries - chose a strategy of extending their local brands to international recognition. One example is China's consumer electronics group Hisense that sells air conditioners, PCs flat-screen TVs, and telecoms equipment under its own brand. It manufactures in Algeria, Hungary, Iran, Pakistan, and South Africa.

Other examples of EMMNEs that chose a strategy of extending their local brands to international recognition are reported in a study of the global white goods industry (Bonaglia et al., 2007). This study posits that Haier (China), Mabe (Mexico), and Arçelik (Turkey) have leveraged their strategic partnerships with established MNEs to upgrade their operations, evolving from the production of simple goods into new product lines developed through their own design, branding, and marketing capabilities. The recipe for their success has been "the ability to treat global competition as an opportunity to build capabilities, move into more profitable 
industry segments, and adopt strategies that turn latecomer status into a source of competitive advantage" (Bonaglia et al., 2007: 380-81). The authors of this study conclude that "their experiences show that there are many strategies and trajectories for going global" (p. 369). At any rate, these EMMNEs now use their own brands as they become global. Lenovo has aggressively expanded the ThinkPad brand acquired from IBM away from traditional laptop computers in favor of tablets and hybrid devices using its own name, and Arçelik is now expanding in Europe through its own Beko brand. Another example is the assertion that EMMNEs do not enjoy FSAs in technology - for many EMMNEs this assertion has become obsolete. The next section explains this.

\section{THE WORLD MAY NOT BE FLAT BUT IT IS RAPIDLY CHANGING}

The world of 2013 is clearly very much different than that of 1977, when the OLI paradigm was first suggested. One result of the digital revolution is the creation of new industries such as semiconductors (Mathews and Cho, 2000) telecommunications, or IT in which advanced countries' MNEs do not necessarily enjoy a competitive advantage or lengthy experience and did not achieve an oligopolistic dominance. Newly created knowledge-based EMMNEs were able to leapfrog this potential disadvantage. They captured globally competitive positions in relatively shorter time spans. One example - already discussed - is Lenovo; another is the Ali-baba Group of China. Founded in 1999, it has aspired to help make the Internet accessible, trustworthy and beneficial for everyone. It has since developed leading businesses in consumer e-commerce, online payment, business-to-business marketplaces, and cloud computing, reaching Internet users in more than 240 countries and regions. The Ali-baba Group consists of 25 business units and is focused on fostering the development of an open, collaborative and prosperous e-commerce ecosystem. The group employs some 24,000 people around the world and has more than 70 offices in Greater China, India, the United Kingdom, and the United States. It is the largest e-commerce company in China, with 2011 revenues of $\$ 2.8$ billion. Other prominent examples are the Chinese Huawei or the Indian Tata Consultancy Services. Indeed, EMMNEs in IT technology were able to compete against established advanced country competitors. Pharmaceutical firms, in contrast, avoided such competition and concentrated on the production and distribution of generics. Several EMMNEs do enjoy local engineering excellence and innovation capabilities. These can be turned into innovation on a global scale, as the Brazilian 
Embraer has done (Embraer was also supported by the Brazilian government). Further, the liberalization policies, the deregulation and developments in information technology have combined to minimize barriers to entry and in many industries a firm may need fewer ownership advantages to initiate internationalization. Moreover, firms do not have to be giants or even large to internationalize. At the same time firms from all countries in the world find it necessary to increase scale and become MNEs in order to be able to compete in an interconnected global arena. Finally, with time, EMMNEs have learned and gained experience. Many of them have moved from being just low-cost producers to become innovators. The low-cost Ascend D1 quad from Huawei Technologies is among the fastest smart phones in the world. In this firm 46 percent of the 150,000 employees engage in R\&D. Mindray, the largest medical equipment manufacturer for both human and veterinary use in China generates more U.S. patents per revenue dollar than many global leaders. In 2011, companies from China were granted more U.S. patents than companies in Israel, Australia, Italy, Netherlands, Sweden, and Switzerland. India also ranked in the top 15 for the first time (BCG, 2013: Exhibit 6).

More generally, when the first wave of EMMNEs was discussed, the geography of innovation by business firms was largely congruent with the exclusive club of the so-called "triad." Developing countries were mainly suppliers of talent by brain drain to developed countries. South Korea was the first country able to reverse the trend, bringing talent back, followed by China and India - in both, contract research organizations (CROs) were created to provide R\&D off-shoring (Bruche, 2009). Indian multinationals are reversing the brain drain by bringing non-resident Indians back from America and Europe, where they have gained experience that could be useful at the center. In the 21st century, EMMNEs - mainly in the leapfrogging industries - cooperate as equal technology partners rather than looking for technology transfers. The Chinese National Chemical Corporation (ChemChina) formed a 50/50 joint venture in 2012 with DuPont that combines DuPont's leading fluoroelastomer technology with ChemChina's integrated manufacturing. The venture will produce fluoroelastomer gums and precompounds. These have wide chemical resistance and superior performance, especially in high-temperature applications in different media. The signing of the joint venture contract is an example of the successful cooperation between DuPont and ChemChina. "It will have a positive impact on our technology base and international market exposure while establishing a good foundation for future cooperation between DuPont and ChemChina," said Hu Dongcheng, president of ChemChina subsidiary China Haohua Chemical Group (Dupont, 2012).

All in all, the real issue is not whether or not EMMNEs as a group enjoy 
FSAs or are able to innovate or to sustain global brands. The relevant question is why some firms are able to achieve these advantages and others not. While part of the answer is in the impact of different contingency variables, other parts may be the result of innovative strategies and simply luck. The rest of this chapter discusses a few of these variables.

\section{INDUSTRY AS A CONTINGENT VARIABLE}

Clearly, the key factors for success are different in different industries. So are the structure of the industry, the regulatory regime within which it operates, and the length at which products are replaced. The airline industry is governed by a regulatory regime designed after World War II that prevents airlines from globalizing through international acquisitions. This regime also restricts take off and landing rights and requires national ownership (Aharoni, 2004). Deregulation in some countries has allowed the creation of low-cost carriers. One of these carriers is Air Asia, based in Malaysia. It is Asia's largest low-fare, no-frills airline. In 2011, it reported the lowest per-available-seat cost per kilometer traveled in the world and revenues of more than $\$ 1.4$ billion.

In the pharmaceutical industry, EMMNEs failed to close the gap with their competitors from advanced economies on both scale and innovation of new drugs. These firms, such as Ranbaxy or Dr Reddy's Limited (DRL) and Sun Pharmaceutical Industries from India, or Aspen from South Africa, concentrate on generics and are sizably smaller compared to the major conventional pharmaceutical companies - their sales are less than a few percentage points off those of Pfizer or Roche.

In contrast, in IT services, knowledge-based EMMNEs have captured globally competitive positions in relatively shorter time spans. They demonstrated a leapfrogging internationalization trajectory leading to fast catch-up in competitiveness with conventional MNEs. These industries are also characterized by a very short life of products that are replaced by new ones. Management of these industries must therefore develop what Teece et al. (1997) have termed dynamic capabilities, defined as "the firm's ability to integrate, build, and reconfigure internal and external competences" to address rapidly changing environments. At the other end, in oligopolistically structured industries such as packaged software or branded consumer goods segments, the barriers to entry are still very high for a market-based entry. The catch-up process - if left to market forces - may be very long. Despite much talk about the globalization of health care, it is still tightly regulated by governments in most countries. The only globalization of health care is in the so-called medical tourism. 
A final example is accounting firms, found not to follow the theory about manufacturing MNEs (Aharoni, 1999). As one example, FDI theory attempts to explain why firms invest abroad rather than export. It assumes that MNEs must overcome a liability of foreignness. Therefore, MNEs must possess an exploitable factor that creates an oligopolistic advantage abroad. Thus, one would expect that the probability of foreign investment would be higher as the firm enjoys higher ownership advantage. Further, the theory assumes MNEs will seek control and full ownership to protect their firm-specific advantages, and additionally, restrictions resulting from bargaining obsolescence force firms to agree to joint ventures. According to Porter (1990: 56): "Choosing a domestic focus in a global industry is perilous no matter what the firm's home market is." He claims that when competition in each nation is essentially independent, the industry is multi-domestic, such as banks and life insurance firms. In contrast, in global industries firms are compelled to compete internationally in order to achieve or sustain competitive advantage. Firms compete on global market share. Yet most accountants, consultants, lawyers, engineers, and management consultants are small domestic firms, with only a few being giant global MNEs.

Specifically, regarding emerging markets, the MNEs in professional services are all from advanced countries. Of course, government policies of massive support of selected state-owned champions may change this picture. One example is China's state-owned aerospace and defense company, Aviation Industry Corporation of China (AVIC), which had 2011 revenues of $\$ 40.5$ billion. AVIC is investing heavily to become a leading competitor in the wide-bodied commercial aircraft market. Another example is Chinese high-speed trains. To be sure, such government support may eventually trigger political reactions in the developed world (for a discussion of this, see Aharoni, 2013).

Other industries often dominated by state-owned or state-supported enterprises are oil and minerals industries and security-related industries. Most countries take for granted that natural resources belong to all citizens of the state, that a private firm should pay royalties to the nation for exploiting its natural resources - be it oil, gas, copper, iron, or diamonds. Further, these firms - even when privately owned - are often asked to achieve political goals. Private firms, for their part, often coerce the government to help them avoid nationalizations or to topple a regime considered unfriendly. The history of Mussadek in Iran and Allende in Chile are two well-known examples. Indeed, the story of oil in particular and energy in general is not one of a free unfettered market. Rather, it is a story of power, military considerations, and security needs. Private firms are behemoths with much political clout and often have joint ventures with 
SOEs. In short, natural resource firms are very different than manufacturing firms - low or high tech - as well as from service firms. Governments want to control natural resources irrespective of their ownership. For that reason, many countries, irrespective of their ideological proclivities, establish SOEs to control natural resources, particularly oil - state-owned oil firms have been established in Saudi Arabia, Italy, and France. At the same time, large oil firms such as British Petroleum are not immune to government direction.

Indeed, an important contingent variable is the role of government. The state can and does hurt or help any business firm. It can also share risks or absorb them. Another contingent variable is social norms and institutions. Institutions in the United States are based on a strong ideological belief in the superiority of the individual. Other countries cherish reciprocal aid of individuals as a part of the community. The culture of guanxi (connections) in China leads to yet different institutions. Countries also differ in the degree to which their citizens rely on trust, loyalty, and authority. Members of the diamond exchange move millions of dollars without any legal document - based on a trust in other members of the clan. Both these variables are discussed extensively by Aharoni (2013). Another - and a related one - is ownership, discussed below.

\section{OWNERSHIP AS A CONTINGENT VARIABLE}

The rise of sovereign wealth funds (SWFs) and SOEs together with statecontrolled entities (SCEs) has led to concerns that SCEs could threaten national security by following political rather than mere commercial goals with respect to their FDI. While developed countries acknowledge that the rise of SCEs should not lead to new barriers to FDI, several, such as Germany in 2009, have changed their legislation to expand government oversight of FDI flows.

The desire for different ownership and control levels may be important reasons for different objectives pursued, and different strategies. It is often claimed - mainly by Western scholars - that family-owned firms are better managed while government ownership means inefficiency, waste, and political patronage. State-owned enterprises are assumed to pursue strategies based on political considerations rather than on the pursuit of commercial objectives. Their strategic orientation, posture and behavior are based on different institutional factors than private enterprises. Ownership advantages may be based on political largesse. These assertions are often made about China. Not only are the largest Chinese MNEs state-owned, but the Chinese government is said to vet investment projects abroad 
and to promote those that fit its development strategy with significant financial support. This is interpreted to mean that Chinese MNEs could, in principle, respond to a centralized strategy that deliberately concentrates higher value-added activities in China, while pushing companies to expand mining and oil extraction in Latin America and Africa, in this way mitigating China's lack of natural resources. However, a closer look at the strategy followed by Chinese oil and mining companies in Latin America shows it to be similar to that of their European and North American peers: they look for vertical integration and a hedge against price fluctuations.

Several researchers are more interested in the effect of state ownership on the strategy and competitive advantage of these SOEs. Unfortunately, too often their conclusions are based on ideological beliefs, not facts. For example, The Economist published a special report on state capitalism (The Economist, 2012) that concluded that SOEs should be privatized because they are not doing well (see also Bremmer, 2010). But this conclusion was based on values about how societies should be run, not on any economic or business theory. In fact, there are many examples of efficient and innovative SOEs, such as Singapore's SWF, Temasek, or Brazil's EMBRAER. Qatar airways, the state-owned flag carrier of Qatar, were recognized as the world's best airline by the Skytrax World Airline Award. Further, most studies of the performance of SOEs compare these firms to an ideal of a perfect market with full information (Aharoni, 1986, 2000).

Yet, ownership per se does not matter. The important determinant of performance is how managers and directors are nominated, chosen, and compensated. If they are chosen and nominated for political reasons, then they are politically oriented. If, on the other hand, they are chosen because of their professional qualifications and are compensated on the basis of commercial success, there is no reason to assume any difference between an SOE and any well-managed, private investor-owned firm, either in an emerging market or a developed-economy market. The relations between governments and managers of SOEs can be structured to achieve efficiency rather than political power (Aharoni and Ascher, 1998). As a recent example, the UK created the UK Financial Investments Limited on November 3, 2008. The UKFI is set up as a company under the Companies Act with the Treasury as the sole shareholder. The stated goal of the structure is to adopt institutional arrangements for keeping UKFI at arm's-length from the government, centered on a heavyweight UKFI board to make all major decisions. Israel also enacted a law to shield the nationalized banks from political interference or patronage. Norway has protected its SWF and state oil company from political interference by enacting such a law.

On the other hand, in some economic activities, such as oil and other 
energy sources, governments tend to interfere in the operations of the markets. However, the intervention is not restricted to SOEs, but applies equally to investor-owned firms. Even the ardent believers in unfettered markets tend to agree that governments should regulate certain economic activities, be it for security reasons or because of market failures. Governments have many tools of intervention, of which ownership is one. When the relations between governments and SOEs are not clearly specified, the SOE managers are faced with a problem of goal ambiguity. They have to juggle, not really knowing how they are expected to make tradeoffs between commercial goals and a variety of externally imposed social or political objectives. In this situation, they may simply take care of their own interests. Since they want to be autonomous, they buy their discretion by acquiring political support. The desire to maximize political support also causes the managers to increase - perhaps unnecessarily - capital investments. Thus, SOE managers may lose political support if electricity shortages occur much more than the investment made into needed capacity (Aharoni, 1986).

\section{OTHER CONTINGENT VARIABLES}

The discussion of contingent variables above is certainly not exhaustive. Other variables may also turn out to be important, such as the size of firms or the size of the home country, or the structure of business government relations.

Most theories of international business have originated in the United States; thus the need of a large home market is taken for granted. Michael Porter, in his discussion of the competitive advantage of nations, emphasized the necessity of a large home market in his "diamond" (Porter, 1990). Yet firms from small countries can and do establish positions in a large country such as the United States, taking advantage of what Rugman and D'Cruz (1993) called the "double diamond." In other words, the firm from the small country, facing conditions that make it difficult for it to grow locally, will internationalize by establishing a base in a large country such as the United States (Aharoni, 2009). Further, it is important to avoid dogmas of "generic strategies." The industry analysis is crucial, but a firm would be much more successful creating a new industry, or defining a welldifferentiated segment within an industry that it can dominate, avoiding direct competition with established firms. Indeed, different EMMNEs are able to operate internationally based on different strategies and different FSAs. In some cases, the firm expands its production internationally because rapid growth in the large home market gives the firms scale 
advantages and spare cash to invest abroad. The management learns to operate in the difficult emerging market and become adaptable and resilient. It also learns to adapt to the liberalization of the home market - as in India since the early 1990s - and to compete against advanced countries' multinationals. Further, management gets exposed to best international practice - after years of protection that weakened them. On the other hand, as discussed above, small firms from small countries may internationalize to gain scale in a larger market. Successful start-ups in the international field concentrate on a small segment of the industry that could be differentiated. For example, Embraer did not compete against Boeing or Airbus. Instead, it became the world's leading maker of regional jets and has overtaken Canada's Bombardier combining low-cost manufacturing with advanced R\&D. Embraer also has a joint venture with China Aviation Industry Corporation.

There are other examples of knowledge-based firms from emerging economies. Almost all of these firms are relatively small. Their strategy is to concentrate on a well-defined market niche. Strategy is all about being unique (Aharoni, 1993) - not about competing in an industry. A really good strategy is not to compete within an industry, but to create an industry. A successful firm does not want to be part of a population. It wants to be unique, because that is the best way to be successful in this very competitive world. The best way is not to compete against ten other firms in the same industry with the same product, but to concentrate on a segment that can be differentiated. As one example, the Israeli based SodaStream is the world's leading manufacturer and distributor of home beverage carbonation systems, which enable consumers to transform ordinary tap water instantly into carbonated soft drinks and sparkling water. These products may be seen as a part of the $\$ 265$ billion sparkling beverages industry, in which Coca Cola is a major player (the market share of Sodastream in this industry is 0.0076 percent). However, in the house carbonation systems' \$200 million market, Sodastream is a dominant player with 85 percent market share. Their products are available at more than 60,000 points of sale worldwide in 45 countries around the world.

Indeed, SMEs compete successfully if they are able to be a major player in a well-defined narrow product category, thus gaining undisputable competitive advantage and achieving global dominance. Other firms have been able to achieve world leadership by exploiting a resource abundantly or inexpensively available in the home country. Brazilian company Vale has become one of the world's leading suppliers based on the cheap sources of iron ore in Brazil. Sadia and Perdigão, also Brazilian, have built sales organizations around the world to make the most of the abundant resources and ideal growing conditions for producing pork, poultry, 
and grain in Brazil. The Mexican company Cemex realized cement is considered bulky, basic, and too expensive to transport long distances. Thus, shipping cement from Mexico to Europe is not profitable. Instead, it acquires or builds local firms, supplying know-how and investment in what it calls "the Cemex way" - very heavily dependent on standardized procedures and systems built around highly developed IT systems.

\section{CONCLUSIONS}

Perhaps in response to the rapidly changing environment around them, EMMNEs internationalize very rapidly. These enterprises pursue different strategies compatible with the size of their home country, the magnitude of their operations, the characteristics of the industry in which they operate, the availability of financial resources, and the capabilities required for success. They tend to penetrate foreign markets by acquiring domestic firms and thus management and access to consumers. Some of them succeed in their internationalization through technological advantages. Others do so through organizational innovations that successfully adapt to the circumstances of the global economy. Other firms are extremely successful because they focus on a very clear segment that they are able to dominate, starting with a small segment and growing to a larger one. Also, EMMNEs develop a global supply chain in which each country specializes in the part of the product or service for which it enjoys a comparative advantage. The successful firms have learned, enhanced their capabilities, and adapted swiftly to changing circumstances.

By 2013, many EMMNEs found that their cost advantage over competitors from mature markets was eroding. They have responded by building new capabilities - such as offering higher-quality products, strengthening their brand, investing in $\mathrm{R} \& \mathrm{D}$, or acquiring foreign firms to gain market access, managerial knowledge, and firm capabilities. Many of them were also able to strengthen their cash resources, taking advantage of the available low interest rates. These EMMNEs have very few things in common. They are different, and understanding their operations calls for a contingency theory. The MNE is crucial for economic growth and for innovation. These enterprises have become a dominant force not only in technology generation and economic well-being, but also in shaping national and international politics. The managers of the MNE attempt to generate valuable resources and capabilities that cannot be easily imitated by rivals. Economic globalization has been accompanied by extensive developments in national and international norms regulating investment and its impact including investment law, natural resource law, and human 
rights law. These norms affect the way the costs, risks, and benefits of investments are shared among the multiple parties involved. Managers of EMMNEs will have to adapt to the changing norms in addition to adaptation to new technologies, more so if they are state owned or controlled.

Moreover, the global landscape is constantly and quickly changing. Social scientists can rarely rely on immutable laws of nature. Many things that were true several decades ago are not true today. Globalization has been accompanied by extensive developments in national and international norms regulating investment and its impact including investment law, natural resource law, human rights law, and security-related laws as well as the OECD proposed rules and norms. Firms undertake FDI because it improves their access to markets and resources and hence increases their international competitiveness, as they seek to maximize the benefits of this investment in the framework of their global corporate networks. This difference in objectives and frameworks gives rise to tensions that play themselves out in the approach governments take in national FDI policies and bilateral investment treaties (BITs).

This chapter has addressed all of this and underscored the need for a contingency approach to explain EMMNE behavior and performance. The chapter has argued that no all-encompassing theory can comprehensively explain the recent internationalization of EMMNEs; thus, international business scholars need to develop contingency theories to describe, explain, and predict this emerging phenomenon.

\section{REFERENCES}

Aharoni, Y. (1986). The Evolution and Management of State Owned Enterprises. Cambridge, MA: Ballinger.

Aharoni, Y. (1993). "In Search of the Unique: Can Firm Specific Advantages be Evaluated?" Journal of Management Studies, 30(1), 31-49.

Aharoni, Y. (1999). "Internationalization of Professional Services: Implications for Accounting Firms." in D. Brock, M. Powell and C.R. (Bob) Hinings (eds), Restructuring the Professional Organization, London: Routledge, pp. 20-40.

Aharoni, Y. (2000). "The Performance of State Owned Enterprises," in P. Angelo Toninelli (ed.), The Rise and Fall of State-Owned Enterprise in the Western World, Cambridge, UK: Cambridge University Press, pp.49-72.

Aharoni, Y. (2004). "The Race for FDI in Services - The Case of the Airline Industry," in P. Ghauri and L. Oxelheim (eds), European Union and the Race for Foreign Direct Investment in Europe, Amsterdam: Elsevier, pp. 381-406.

Aharoni, Y. (2009). "Multinationals from Israel," in R. Ramamurti and J. Singh (eds), Emerging Multinationals from Emerging Markets, Cambridge, UK: Cambridge University Press, pp. 352-96.

Aharoni, Y. (2013). "The Road to Relevance," in T. Devinny, T. Pedersen and L. Tihanyi (eds), Advances in International Management: Volume 26-Philosophy of Science and MetaKnowledge in International Business and Management, Bingley, UK: Emerald, pp. 127-69. 
Aharoni, Y. and W. Ascher (1998). "Restructuring the Arrangements Between Government and State Enterprises in the Oil and Mining Sectors," Natural Resources Forum, 22(3), 201-13.

Bonaglia, F., A. Goldstein and J. Mathews (2007). "Accelerated Internationalization by Emerging Multinationals: the Case of White Goods Sector," Journal of World Business, 42(4), 369-83.

Boston Consulting Group (BCG) (2013). "Introducing the 2013 BCG Global Challengers." Available at: https:/www.bcgperspectives.com/content/articles/globalization_growth_ introducing_the_2013_bcg_global_challengers (accessed October 19, 2014).

Bremmer, I. (2010). The End of the Free Market: Who Wins the War Between States and Corporations? New York: Penguin.

Bruche, G. (2009). "The Emergence of China and India as New Competitors in MNCs' Innovation Networks," Competition and Change, 13(3), 267-88.

Buckley, P.J., L.J. Clegg, A.R. Cross, X. Liu, H. Voss and P. Zheng (2007). "The Determinants of Chinese Outward Foreign Direct Investment," Journal of International Business Studies, 38, 499-518.

Buckley, P.J. and M.C. Casson (1976). Inside the Multinationals. London: Macmillan.

Buckley, P.J. and M.C. Casson (2009). "The Internalization Theory of the Multinational Enterprise: A review of the Progress of a Research Agenda After 30 Years," Journal of International Business Studies, 40, 1563-80.

Cantwell, J. and H. Barnard (2008). "Do Firms from Emerging Markets have to Invest Abroad? Outward FDI and the Competitiveness of Firms," in K.P. Sauvant (ed.), The Rise of Transnational Corporations From Emerging Countries - Threat Or Opportunity? Cheltenham, UK and Northampton, MA, USA: Edward Elgar, Chapter 5.

Coase, R.H. (1937). "The Nature of the Firm," Economica, 4(16), 386-40.

Cuervo-Cazurra, A. (2012). "How the Analysis of Developing Country Multinational Companies Helps Advance Theory: Solving the Goldilocks Debate," Global Strategy Journal, 2(3), 153-67.

Cuervo-Cazurra, A. and M. Genc (2008). "Transforming Disadvantages into Advantages: Developing-Country MNEs in the Least Developed Countries," Journal of International Business Studies, 39(6), 957-79.

Dunning, J.H. (1958). American Investment in British Manufacturing Industry. London: Allen \& Unwin.

Dunning, J.H. (1977). "Trade, Location of Economic Activity and the MNE: A Search for an Eclectic Approach," in B. Ohlin, P.-O. Hesselborn and P.M. Wijkman (eds), The International Allocation of Economic Activity, London: Macmillan, pp. 395-418.

Dunning, J.H. (2006). "Comment on Dragon Multinationals: New Players in 21st-Century Globalization," Asia Pacific Journal of Management, 23(2), 139-41.

Dunning, J.H., C. Kim and D. Park (2008). "Old Wine in New Bottles: A Comparison of Emerging-Market TNCs Today and Developed-Country TNCs Thirty Years Ago," in K.P. Sauvant (ed.), The Rise of Transnational Corporations From Emerging Countries Threat Or Opportunity? Cheltenham, UK and Northampton, MA, USA: Edward Elgar, Chapter 8.

Dunning, J.H. and S. Lundan (2008). Multinational Enterprises and the Global Economy. Cheltenham, UK and Northampton, MA, USA: Edward Elgar.

Dupont (2012). "Chenguang Chemical Research Institute Announce Signing with DuPont." Available at: http://www.dupont.com/products-and-services/plastics-polymers-resins/ elastomers/press-releases/chenguang-sign-agreement.html (accessed October 19, 2014).

The Economist (2012). "The Rise of State Capitalism," 21 January. Available at: http://www. economist.com/node/21543160 (accessed November 13, 2012).

Forsgren, M. (2013). Theories of the Multinational Firm: A Multidimensional Creature in the Global Economy. Second Edition. Cheltenham, UK and Northampton, MA, USA: Edward Elgar.

Goldstein, A. (2007). Multinational Companies from Emerging Economies: Composition, Conceptualization and Direction in the Global Economy. London: Palgrave Macmillan. 
Goldstein, A. (2008a). "A Latin American Global Player Goes to Asia: Embraer in China," International Journal of Technology and Globalisation, 4(1), 56-69.

Goldstein, A. (2008b). "Emerging Economies' Transnational Corporations: The Case of Tata," Transnational Corporations, 17(3), 85-108.

Goldstein, A. (2009). "Multinational Companies From Emerging Economies Composition, Conceptualization and Direction in the Global Economy," Indian Journal of Industrial Relations, 45(1), 520-35.

Goldstein, A. and P. Pananond (2008). "Singapore Inc. Goes Shopping Abroad: Profits and Pitfalls," Journal of Contemporary Asia, 38(3), 417-38.

Ghymn, K.I. (1980). "Multinational Enterprises from the Third World," Journal of International Business Studies, 11, 118-22.

Hennart, J.F. (2012). "Emerging Market Multinationals and the Theory of the Multinational Enterprise," Global Strategy Journal, 2, 168-87.

Hoskisson, R.E., L. Eden, C.M. Lau and M. Wright (2000). "Strategy in Emerging Economies," Academy of Management Journal, 43(3), 249-67.

Hymer, S. (1976). The International Operations of National Firms: A Study of Direct Foreign Investment. Cambridge, MA: MIT Press.

Jones, G. (2005). Multinationals and Global Capitalism. Oxford and New York: Oxford University Press.

Jones, G. and T. Khanna (2006). "Bringing History (Back) into International Business," Journal of International Business Studies, 37(4), 453-68.

Kumar, K. and M.G. McLeod (eds) (1981). Multinationals from Developing Countries. Lexington, MA: Lexington Books.

Lall, S. (1983). The New Multinationals: The Spread of Third World Enterprises. New York: Wiley.

Lecraw, D. (1977). "Direct Investment By Firms From Less Developed Countries," Oxford Economic Papers, 29, 445-57.

Lessard, D. and R. Lucea (2009). "Mexican Multinationals: Insights from CEMEX," in R. Ramamurti and J. Singh (eds), Emerging Multinationals in Emerging Markets, Cambridge, UK: Cambridge University Press, pp. 280-311.

Luo, Y. and R.L. Tang (2007). "International Expansion of Emerging Countries Enterprises: A Springboard Perspective," Journal of International Business Studies, 38(4), 481-98.

Mathews, J.A. (2002a). Dragon Multinationals. New York: Oxford University Press.

Mathews, J.A. (2002b). "Competitive Advantages of Latecomer Firms: A Resource-Based Account of Industrial Catch-Up Strategies," Asia-Pacific Journal of Management, 19(4), $467-88$.

Mathews, J.A. 2006a. "Dragon Multinationals: New Players In 21st Century Globalization,” Asia-Pacific Journal of Management, 23(1), 5-27.

Mathews, J.A. (2006b). "Response to Professors Dunning and Narula," Asia-Pacific Journal of Management, 23(1), 153-5.

Mathews, J.A. and D.S. Cho (2000). Tiger Technology: The Creation of a Semiconductor Industry in East Asia. Cambridge, UK: Cambridge University Press.

Narula, R. (2006). "Globalization, New Ecologies, New Zoologies, and the Purported Death of the Eclectic Paradigm," Asia Pacific Journal of Management, 23(2), 143-51.

Narula, R. (2010). "Keeping the Eclectic Paradigm Simple," Multinational Business Review, $18(1), 35-50$.

Narula, R. (2012). "Do We Need Different Frameworks to Explain Infant MNEs From Developing Countries?" Global Strategy Journal, 2(3), 188-204.

Porter, M. (1990). The Competitive Advantage of Nations. New York: The Free Press.

Ramamurti, R. (2009). "What Have We Learned About Emerging Market MNEs?" in R. Ramamurti and J. Singh (eds), Emerging Multinationals in Emerging Markets, Cambridge, UK: Cambridge University Press, pp. 399-426.

Ramamurti, R. (2012). "What is Really Different About Emerging Market Multinationals?" Global Strategy Journal, 2(1), 41-7.

Ru-Shiun, L., A.S. Rose and A.E. Ellstrand (2012), "Emerging-Market Multinational 
Corporations as Agents of Globalization: Conflicting Institutional Demands and the Isomorphism of Global Markets," in L. Tihanyi, T.M. Devinney and T. Pedersen (eds), Institutional Theory in International Business and Management (Advances in International Management, Volume 25), Bingley, UK: Emerald, pp.179-206.

Rugman, A.M. (1981). Inside the Multinationals: The Economics of Internal Markets. London: Croom Helm.

Rugman, A.M. (2009). "Theoretical aspects of MNEs from emerging economies," in R. Ramamurti and J.V. Singh (eds), Emerging Multinationals in Emerging Markets, Cambridge, UK: Cambridge University Press, pp. 42-63.

Rugman, A.M. and J.R. D'Cruz (1993). "The 'Double Diamond' Model of International Competitiveness: The Canadian Experience," Management International Review, 33, $17-39$.

Rugman, A.M. and J. Li (2007). "Will China's Multinationals Succeed Globally or Regionally?" European Management Journal, 25(5), 333-43.

Teece, D.J., G. Pisano and A. Shuen (1997). "Dynamic Capabilities and Strategic Management," Strategic Management Journal, 18(7), 509-33.

UNCTAD (2013). World Investment Report 2013: Global Value Chains: Investment and Trade for Development. Available at: unctad.org/en/publicationslibrary/wir2013_en.pdf (accessed October 19th, 2014).

Vernon, R. (1971). Sovereignty at Bay: The Multinational Spread of U.S. Enterprises. New York and London: Basic Books.

Wang, C., J. Hong, M. Kafouros and M. Wright (2012). "Exploring the Role of Government Involvement in Outward FDI From Emerging Economies," Journal of International Business Studies, 43, 655-76.

Wells, L. (1983). Third World Multinationals: The Role of Foreign Direct Investment from Developing Countries. Cambridge, MA: MIT Press.

Williamson, P.J. and M. Zeng (2009). "Chinese Multinationals: Emerging Through New Global Gateways," in R. Ramamurti and J. Singh (eds), Emerging Multinationals in Emerging Markets, Cambridge, UK: Cambridge University Press, Chapter 6.

Zaheer, S. (1995). "Overcoming the liability of foreignness," Academy of Management Journal, 4(1), 341-63.

Zeng, M. and P. Williamson (2007). Dragons at Your Door: How Chinese Cost Innovation is Disrupting Global Competition. Boston, MA: Harvard Business School Press. 